\title{
EVALUATION OF THE DEVELOPMENT OF VARIOUS FORMS OF AGRICULTURE COOPERATION IN THE REPUBLIC OF KAZAKHSTAN
}

\author{
Galiya Akimbekova ${ }^{1 *}$, Elena Horská2 , Gulnur Yegizbayeva' \\ "LLP "Kazakh Research Institute of Economy Agribusiness and Rural Development" Almaty, Republic of Kazakhstan \\ 2Slovak University of Agriculture in Nitra, Slovak Republic
}

\begin{abstract}
The article analyzes the current situation in the agricultural complex of the Republic of Kazakhstan, the necessity of combining small farms in the cooperative structure, evaluation of existing forms of cooperatives in agriculture are substantiated (production cooperatives, rural consumer cooperatives, rural consumer cooperatives of water users), a map of their location in the context of regions of the country is shown, problems hindering their development are revealed, particularly the formation and development trends of each of them, the economic indicators of production of products are given, together with their organizational structure, etc. On the basis of the conducted analysis of the production conditions, rural consumers and rural consumer cooperatives of water users, problems hindering their development are revealed, the positive and negative trends in the development of various forms of agricultural cooperation are assessed, and proposals has been substantiated in order to improve the regulatory framework, mechanisms of state support, credit and financial mechanisms, etc.
\end{abstract}

Keywords: agricultural cooperatives, evaluation, forms, development

\section{Introduction}

International experience confirms the high efficiency of agricultural cooperatives, and the significant proportion of their weight in agribusiness in developed countries. The main socio-economic problems of an agricultural cooperation is to create organizational and legal system of agricultural producers' interests protection in the conditions of market relations by creating democratically based self-managed forms of management (Akimbekova, 2012). Interaction of cooperation and marketing is a widely discussed topic today. In the conditions of the formation of the agricultural market in the country, cooperation process has the character of individual attempts of building cooperation ties between the producers and consumers. Therefore, to adapt agricultural production to the market conditions, the conceptual basis for the organization of production enterprises of various forms of management on the basis of their cooperation becomes particularly important.

Rapid transfer to market economy with insufficient development of market infrastructure enhanced the monopoly of processing and trade organizations, the emergence of numerous intermediaries, and reduced the output of production for almost all types of agricultural products. In addition, there have been changes in its structure by types of farms: in agricultural enterprises and farms in the main development of crop and livestock production is concentrated in households. Separation of previously unified production units on the basis of decentralization and privatization on smaller or secondary formation in the agricultural sector makes the subject perceive the processes occurring in the system of economic relations of agriculture, processing and servicing enterprises of agricultural complex, in order to determine the organizational and productive form of interaction, and adequate newly created industrial relations in agriculture. All this is forcing agricultural producers to organize their own joint sales activities, storage and processing the produced agricultural products, logistics and service of agricultural producers without intermediaries on a cooperative basis (Akimbekova, Ayulov and Yegizbayeva, 2015).

\section{Data and Methods}

Today, in the agricultural complex of the republic there are functioning various forms of agricultural cooperation, but they are not widespread. The mechanism of their formation is a large part of the spontaneous, economic mechanism of their functioning and does not respond to the requirements of the times.

Despite the fact that the problems of agricultural cooperation are given a great attention in numerous publications, in the agricultural complex of the republic, cooperative formations are not well developed. Modern agroeconomic science is not based on methodology development of agricultural cooperation and methods for determining the economic efficiency of functioning of agricultural cooperatives with considering the features of the selected model (sales, processing, logistics, production etc.).

Thereby, we have conducted the evaluation of existing forms of agricultural cooperatives (agricultural production cooperatives, rural consumer cooperatives, rural consumer cooperatives of water users), identifying the main trends of development, positive and negative directions, the competitive advantages of new forms of cooperation, as well as determining features of economic mechanism functioning of the various models of cooperation, the mechanism of formation and effective functioning of the prospective forms of agricultural cooperatives (sales, processing, logistics, agroservice, etc.) in a variety of branches of agricultural complex, development of proposals on improvement of the legal framework, measures of government support and regulatory, and formation of beneficial economic relations between the participants of cooperation.

The research used the following methods:

$\square$ Economics and Statistics - when analyzing data of specific production cooperatives in different regions of the Republic of Kazakhstan, the output and potential of production of various types of agricultural products.

$\square$ Monographic - in identifying patterns and principles of the development of agricultural cooperation in the agricultural complex. 
$\square$ Comparative analysis - in order to select the most appropriate and perspective forms of cooperative formations, which have developed in the advanced market economics.

$\square$ Abstract and Logical - in economic substantiating models of cooperative structures, identifying the factors that influence the choice of the model, as well as in the preparation of programs for the development of cooperation in agricultural complex at different levels, considering the regional features.

\section{Results and discussion}

In the republic there have been developed agricultural production cooperatives, the number of which amounted to 1,474 by January 1, 2016, and agricultural service cooperatives in the form of 1,545 rural consumer cooperatives (RCC) (The Law of the Republic of Kazakhstan..., 2014) and 346 rural consumer cooperatives of water users (RCCWU) (The Law of the Republic of Kazakhstan..., 2014). A significant part of the created cooperatives is located in the southern regions (South Kazakhstan, Zhambyl, Almaty) (Figure 1). The share of agricultural cooperatives in the total number of agricultural enterprises is $1 \%$, which confirms the low level of cooperation. Every form of agricultural cooperation has its own features of the mechanism of formation, functioning and trends of the development.

Analysis of production cooperatives activities in the last three years shows that their share is small: in total amount of crop areas of agricultural land (10.2\%), in the cattle production $(6.4 \%)$, the wheat production $(4.1 \%)$, milk $(21.5 \%)$, produced by agricultural enterprises of the republic. The current situation is due to the lack of working capital for the development of production, their considerable debts and thus reducing the number of production cooperatives in 2 times in the last 20 years. This trend is characteristic and for other forms of agricultural enterprises, which led to a small-scale nature of agricultural production, reduction of large specialized agricultural enterprises and an increase in small farms (peasant (farmer) and households. The proportion of households in the total volume of gross agricultural output is $43 \%$, the proportion is especially high in the livestock

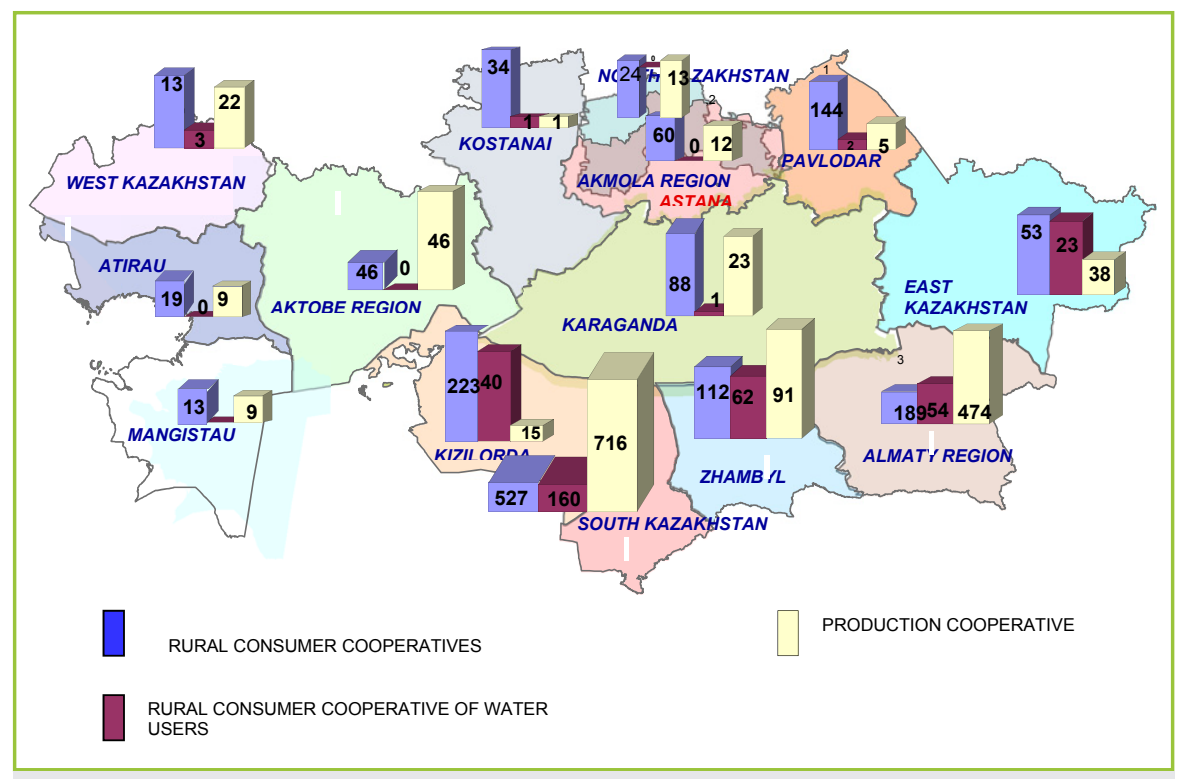

Figure 1 Types of agricultural cooperatives and placement on the regions in the Republic of Kazakhstan by January 1, 2016

Source: Agriculture, Forestry and Fishing of Kazakhstan. Statistical Yearbook, 2011-2016. Agency on Statistics of the Republic of Kazakhstan

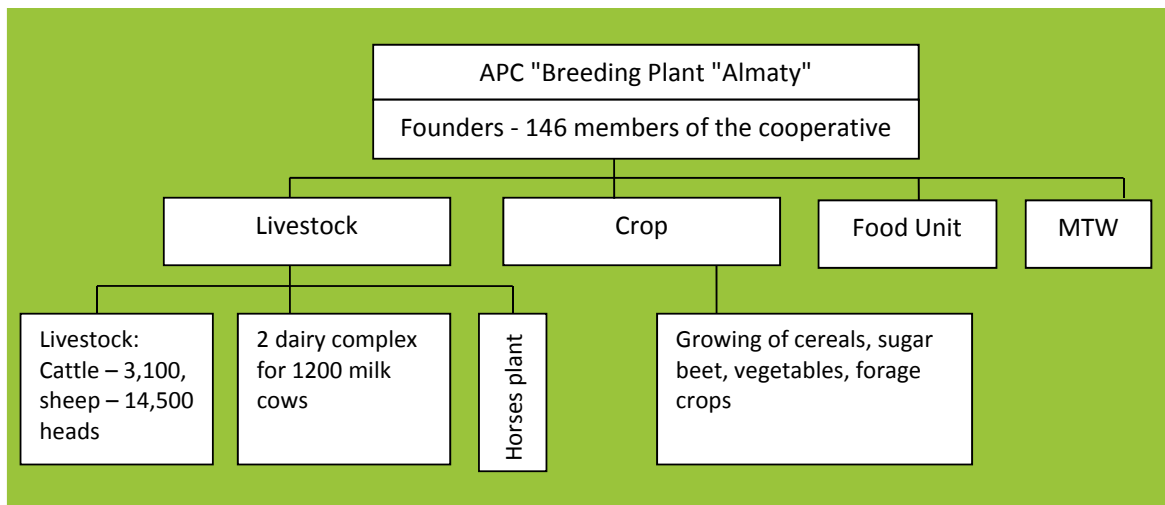

Figure 2 Organizational structure of the agricultural production cooperative "Breeding Plant Almaty" Source: Data of annual reports APC "Breeding Plant"Almaty" Talgar district of Almaty region, 2015

Table 1 Economic efficiency of rural production cooperatives of the Almaty and the South Kazakhstan regions of the Republic of Kazakhstan for 2015

\begin{tabular}{|c|c|c|c|c|c|}
\hline & PC "Kogalym" & PC "Dinara" & $\begin{array}{l}\text { APC"Breeding Plant } \\
\text { "Almaty" }\end{array}$ & PC "Ketebay" & $\begin{array}{l}\text { Mean value, the researched } \\
\text { cooperatives }\end{array}$ \\
\hline Average number of employees, units. & 105 & 142 & 800 & 345 & 348 \\
\hline Cultivated area (ha) & 3,638 & 3,588 & 5,704 & 2,900 & $3,957.5$ \\
\hline $\begin{array}{l}\text { Revenues from sales of products, works and services } \\
\text { (thousand tenge) }\end{array}$ & 89,773 & $386,291.1$ & 504,109 & 295,291 & 318,866 \\
\hline Net profit (thousand tenge) & 19,414 & $87,791.5$ & 67,650 & $71,790.4$ & $61,661.0$ \\
\hline Margin (\%) & 27.6 & 29.4 & 13.4 & 32.1 & 24.0 \\
\hline Gross output per 1 ha of plowed land (thous. tenge) & 24.76 & 107.66 & 88.38 & 101.82 & 80.57 \\
\hline Gross output per employee (thousand tenge) & 854.98 & $2,720.4$ & 630.14 & 855.92 & 916.28 \\
\hline
\end{tabular}

Source: Data of the Department of Agriculture on Statistics of Almaty and South Kazakhstan regions, 2015 
Table 2 Rural consumer cooperatives of water users in the Republic of Kazakhstan on 01.01.2016

\begin{tabular}{|l|c|c|c|c|}
\hline Names of regions & $\begin{array}{c}\text { Number of created } \\
\text { RCCWU }\end{array}$ & $\begin{array}{c}\text { Used for irrigated areas } \\
\text { (thousand ha) }\end{array}$ & $\begin{array}{c}\text { Serviced RCCWU irrigated area } \\
\text { (thousand ha) }\end{array}$ & $\begin{array}{c}\text { Coverage of irrigated } \\
\text { land RCCWU (\%) }\end{array}$ \\
\hline Almaty & 54 & 502 & 81 & 16 \\
\hline East Kazakhstan & 23 & 57 & 22 & 38 \\
\hline Zhambyl & 62 & 165 & 100 & 61 \\
\hline West Kazakhstan & 3 & 4 & 2 & 52 \\
\hline Karaganda & 1 & 54 & 1 & 2 \\
\hline Kostanay & 1 & 5 & 106 & 2 \\
\hline Kyzylorda & 40 & 154 & 5 & 69 \\
\hline Pavlodar & 2 & 9 & 313 & 55 \\
\hline South Kazakhstan & 160 & 443 & 630 & 71 \\
\hline By republic & 346 & 1,392 & 5 & 2 \\
\hline
\end{tabular}

Source: Agriculture, Forestry and Fishing of Kazakhstan. Statistical Yearbook, 2011-2016.Agency on Statistics of the Republic of Kazakhstan

production (70\%) (Agriculture, Forestry and Fishing of Kazakhstan...,).

In order to identify the effectiveness of the functioning of existing agricultural production cooperatives, we analyzed the activity of the largest cooperatives. First of all we surveyed production cooperatives, created in the period of reforming property, privatization of collective farms and state farms.

One of the representatives of the functioning of production' cooperatives in the republic is agricultural production cooperative (APC) "Breeding Plant "Almaty", located in the Talgar district of the Almaty region. The organizational structure of management of the agricultural production cooperative is shown in Figure 2 (Data of annual reports APC..., 20015). The farm cultivates cereals (wheat, barley), the average yield of cereals (rainfed) reached $11 \mathrm{c} \mathrm{ha}^{-1}$ for irrigated land cultivated sugar beets, vegetables, forage crops, perennial grasses (alfalfa), corn silage, and soybean. The farm has a full range of agricultural machinery, equipped with machinetractor workshop (MTW), that allows carrying out all work in the fields to meet their technology. This example of economic activity of the agricultural production cooperative "Breeding Plant Almaty" shows the effectiveness of collective work, which has preserved the collective farming system.

Then, we analyzed the activity of the largest production cooperatives (PC "Kogalym", PC "Dinara", APC "Breeding Plant "Almaty", PC "Ketebay" of Almaty and South Kazakhstan districts), confirming the economic efficiency and benefits of large agricultural companies, producing high-value products. However, as it can be seen from Table 1, the level of profitability is low $(24 \%$ on average for the researched cooperatives), which is associated with significant costs for production, high prices of fuel, spare

\begin{tabular}{|c|c|}
\hline & RCCWU "Dostyk" \\
\hline & $\begin{array}{l}\text { o founded in } 2001 \text { by the decision of general meeting of farms in the } \\
\text { village "Dostyk" consists of } 267 \text { farms, the total area of irrigated land } \\
\text { of RCCWU - } 2,678 \text { hectares }\end{array}$ \\
\hline \multicolumn{2}{|r|}{ Functions: } \\
\hline $\begin{array}{l}\text { o registratic } \\
\text { o equal part } \\
\text { of the con } \\
\text { o creation } \\
\text { managem } \\
\text { o organizati } \\
\text { systems } \\
\text { o making co } \\
\text { o making co } \\
\text { the plann } \\
\text { carrying o }\end{array}$ & $\begin{array}{l}\text { nnd certification of inter-farm irrigation and drainage systems } \\
\text { icipation of members in the management of cooperative activities and implementation } \\
\text { ditions of charter } \\
\text { of a service operation of irrigation and drainage system on a contractual basis, } \\
\text { ent and coordination of its activities } \\
\text { on of activities on repair, operating and improvement of irrigation and drainage } \\
\text { ntracts with relevant water management authorities for getting water } \\
\text { ontracts with water users for the provision of water supply and the implementation of } \\
\text { ed water use } \\
\text { ut trainings, consultations for RCCWU }\end{array}$ \\
\hline
\end{tabular}

Figure 3 Organizational structure RCCWU "Dostyk" Maktaaral district of the South Kazakhstan region Source: Data of RCCWU“Dostyk"Maktaaral district of South Kazakhstan region, 2015 parts, fertilizers, seeds, etc., and insufficient level of state support for large specialized agricultural enterprises.

The following form of agricultural cooperatives in the country includes rural consumer cooperative water users (RCCWU). Today in the republic there are registered 346 units on the area of 630 thousand hectares or $45 \%$ of used irrigated land (Table 2). A significant number of them is located in the south regions: the South Kazakhstan region - 160, the Zhambyl region 62 , the Almaty region - 54, the Kyzylorda region -40 , that explains the irrigated area size serviced by the RCCWU, which amounted in the South Kazakhstan region to 313 thousand hectares, in the Kyzylorda region to 106 thousand hectares, in the Zhambyl region to 100 thousand hectares, in the Almaty region to 81 thousand hectares. The percentage of coverage of irrigated land of the RCCWU (45\% in the country) is as follows: $71 \%$ in the South Kazakhstan region, $69 \%$ in the Kyzylorda region, confirming the significant role of this form of cooperation in the effective use of irrigated land. It should be noted that the employment of the population according to the Agency of Statistics on the irrigated lands is up to 300 people per 1,000 hectares, and the employment of the population on non-irrigated lands is up to 50 people per 1,000 hectares. This confirms not only economic but also social significance of the RCCWU activities.

According to the Law of the Republic of Kazakhstan "On Rural Consumer Cooperatives of Water Users" (The Law of the Republic of Kazakhstan...), a rural consumer cooperative of water users is a voluntary association of agricultural producers for the joint management of hydraulic structures for the needs of agriculture and other services for providing water. Figure 3 
shows the organizational structure of RCCWU "Dostyk", the Mahtaaral district of the South Kazakhstan region, which shows that the cooperative specializes not only in the organization of water supply, but also on the production of agricultural products.

Organizational-economic preconditions for the formation of the RCCWU were the issues that formed during the dissolution of large farms and the creation of small peasant farms. At the same time, water irrigation networks were left without a specific owner's care and technical content what has resulted in the increased wear and decrease in efficiency of irrigating systems, any problems on the making of contracts with the Republican State Enterprises (RSE) and energy suppliers, disruptions of irrigation timing, and conflict for the provision of water between farms and others. The revealed issues contributed to the reduction of the terms of service for constructed vertical drainage wells (Akimbekova et al., 2011).

Lack of funds at the RCCWU and their association on restoration of the idle equipment, on protection of property, scattered in the territory of nearly 50 thousand hectares, etc. problems have proved the need for creating a state structure on exploitation of water facilities. Thus, at RSE "Yugvodkhoz", the Maktaral district of the South Kazakhstan region, the Water Committee of the Ministry of Agriculture is offered to create of specialized services and the transfer of its balance wells of vertical drainage and collector and drainage networks. Today, fully completed work on the re-evaluation of the value of the hydraulic complex, irrigation canal, power lines, pumping stations, but direct transmission mechanism has not worked out, which can lead to the same issues. Experience of many RCCWU for today shows the area of irrigated agriculture that they can carry out not only for water supply functions, and multi-profile. These cooperatives can over time become the integrators to associate the disparate farms to relatively large associations of agricultural producers which can lead to expanded reproduction, to comply with crop rotation, planned output of production for the cooperative and in general to carry out land surveying work aimed at the efficiency of irrigated land in the final by improving the incomes of farms to increase employment in rural areas.

But to achieve this it is necessary to make changes on the part of the expansion of the RCCWU functions except that it is necessary that all the subsidies and transfers supporting and reducing the price of goods of agricultural production were carried out not only through the RCC and RCCWU. Now there is a practice that many RCCWU of the South Kazakhstan region for the expansion of its functions renamed in the RCC, which entails additional costs of re-registration of them and the state control and managing a set of terms and abbreviations is making a lot of contradictions and discrepancies in different structures (Sundetov, 2005).

But the issues of the effective functioning of RCCWU also consist from lack of financial resources for exploitation wells, logistics equipment, which led to an increase in groundwater levels, intense salinization of lands, hence reduction in crop yields, increasing the debt of the peasants. With this aims, RCCWU united in the Association at the district, regional, republican levels, help to protect the interests of farmers. The positive moment for the development of agricultural cooperation in the Republic of Kazakhstan is what in practice of RCCWU for today is expanded their functions, resolve issues not only on providing with water, but also economic (production of agricultural production, providing fuels, equipment, etc.), and social problems (providing rural employment, improving their skills, etc.) (Akimbekova, 2011).

Creation of rural consumer cooperatives (RCC) as a third form of agricultural cooperation in the Republic of Kazakhstan can be characterized as a "process of accelerated formal cooperation". During 2006-2015 there were created about 1,545 RCC. In 2006 started the implementation of the
RCC lending program by JSC "Agrarian Credit Corporation". The main objective of this program was to stimulate agricultural producers in the creation of associations of agricultural infrastructure on preparation, sale, storage and processing of agricultural products.

However, with an increase in the number of RCC, the process of association of agricultural producers was not confirmed. Instead, there were created conditions for private entrepreneurs, combininh two or more legal entities and individuals who have relative ties with the aims to association the estate property and have sufficient collateral property. While agricultural producers, associated in the RCC, but has not received a concessional loandue to lack of collateral property, subsequently disbanded. The main disadvantage is that the RCC were not created with the aim to associate efforts to protect the interests of the cooperative members - agricultural producers, but with the aim to receive a concessional loan (Actual Problems of Development of Cooperation..., 2015).

There are of course also positive examples of the RCC functioning. An example of effective mechanism of formation and functioning of the agricultural serving cooperative in the Republic of Kazakhstan can be noted inthe RCC "Besketik" Maktaaral district of the South-Kazakhstan region. Economic development of the RCC "Besketik" from 2008 to 2016 shows that with the correct approach to the process of cooperation and compliance with its basic principles, one can achieve high economic results in general in cooperative and individual farms included in the cooperative. The RCC "Besketik" was founded on the basis of the voluntary association of 163 farms of rural district "Dostyk" Maktaaral district of South Kazakhstan region. At the same time, farms retained their legal independence and were the owners of their lands, produced products and agricultural machinery (The Law of the Republic of Kazakhstan...).

The advantages of associating farms into the RCC "Besketik" include:

$\square$ members of the cooperative (163 farms) when joining in the RCC retained their legal and economic independence, i.e. were owners of the land, produced products, agricultural machinery;

$\square$ stable sales warranty produced by farms products without intermediaries directly to the cotton processing plant and the implementation of settlements by transfer to the account of farms;

$\square$ reduction of farms expenses for transportation, delivery of raw materials to processing at the expense of cotton plants, as the RCC "Besketik" is their corporative customer;

$\square$ reducing the cost of farms (small and medium) to mechanized services provided by other farms (large) due to the use of internal tariffs for the members of the cooperative, which is lower than the cost of the party organizations are twice;

$\square$ the possibility of obtaining additional income to the large farms having own MTW, by providing mechanical services to small and medium agricultural farms;

$\square$ the possibility of obtaining additional income to the small farms due to providing the services (wage labour) for large agricultural farms;

$\square$ protection of the interests of cooperative members - small, medium and large farms and the right to vote at the general meeting of the founders of the cooperative in the discussion and decision-making of industrial, institutional and economic issues;

$\square$ the possibility to obtaining state subsidies to the farms, concessional lending, taxation for RCC due to centralized preparation of documents by department of cooperative management;

$\square$ the ability to gratuitous obtainining information consulting support from cooperative experts; 
Table 3 Positive and negative directions of the development of forms of agricultural cooperation in the Republic of Kazakhstan

\begin{tabular}{|c|c|c|}
\hline & Positive direction & Negative direction \\
\hline $\begin{array}{l}\text { Production cooperatives }(\mathrm{PC}) \text {, } \\
\text { created in } 90 \text { years }\end{array}$ & $\begin{array}{l}\text { saves advantages of large agricultural specialized farms } \\
\text { (producing high-value pro-ducts, multibranch activities, } \\
\text { and others.), as well as the cooperative principles ("one } \\
\text { member - one vote", and others) }\end{array}$ & $\begin{array}{l}\text { lack of stimulating factors increasing labour productivity } \\
\text { disparity of collective farm system farming to market relations } \\
\text { lack of financial resources for the development of production, debt of enterprises, leading to } \\
\text { their bankruptcy }\end{array}$ \\
\hline $\begin{array}{l}\mathrm{PC} \text { created in recent years } \\
(2005-2010)\end{array}$ & $\begin{array}{l}\text { increase the output and profitability of production } \\
\text { development of infrastruc-ture } \\
\text { use of high-tech equipment and others }\end{array}$ & $\begin{array}{l}\text { operated as a LLP in the interests of a limited number of founders ( } 2-3 \text { individuals) } \\
\text { main aim - profit making, no satisfaction of the needs of cooperative members }\end{array}$ \\
\hline $\begin{array}{l}\text { Rural consumer } \\
\text { cooperative (RCC) }\end{array}$ & $\begin{array}{l}\text { stably increase the number of RCC } \\
\text { providing a concessional loan at } 5 \% \text { for } 5-7 \text { years under the } \\
\text { terms of JSC "Agrarian Credit Corporation" } \\
\text { providing a special tax regime for the RCC } \\
\text { development of infrastructure (construction of processing } \\
\text { facilities, storage facilities, installation of high-tech } \\
\text { equipment, etc.) }\end{array}$ & $\begin{array}{l}\text { violation of cooperative principles (democratic management "one member - one vote", } \\
\text { providing income for the cooperative members, voluntary entry and others.) } \\
\text { formal character of agricultural producers association connected in most cases with a wish to } \\
\text { get concessional lending and taxation, rather than to create an RCC } \\
\text { inaccessibility of concessional lending to small farmers due to the lack of collateral property, } \\
\text { leading to the disbanding of a created RCC } \\
\text { lack of preparation, adaptation stage of RCC organization led to the fact that the adopted } \\
\text { measures of state support (concessional lending and taxation) were used not by farmers, but } \\
\text { by individual private entities, mostly LLP, which have relative ties, with the aim of association of } \\
\text { property ownership and primary possession of individual share in an RCC }\end{array}$ \\
\hline
\end{tabular}

Source: Akimbekova G. Agroindustrial Integration: Theory, Practice, Perspectives. Almaty, Kazakhstan, 2012, 330 p.

$\square$ provision of irrigation and drinking water;

$\square$ ensuring stable employment (full time job and additional work in the seasons).

Realization of these advantages of the RCC "Besketik" contributed to the effective functioning, satisfaction of agricultural producers needs in the provision of certain services, increase of their income and providing of employment for the rural population. The wide dissemination of good experience of operation mechanism of the RCC "Besketik" would make it possible to increase the number of created agricultural service cooperatives in Kazakhstan (Data of annual reports of RCC..., 2015) ).

Thus, the analysis of existing agricultural cooperatives of the republic helps to identify their existing form (PC, RCC, RCCWU), the features of the mechanism of economic relations between the parties of cooperation, and the positive and negative directions of the development of each models (Table 3).

\section{Conclusion}

An analysis of the situation in the agricultural complex of Kazakhstan shows that the opportunities and advantages of agricultural cooperatives have not yet been fully realized, its role and importance in the socio-economic development of the country is underestimated. As a result, state support that has been adapted, the agricultural cooperatives in the country in particular did not give proper effect of protecting the interests of small farms by associations. Unfortunately, there is still a slightly used potential reserve in the formation of food stocks.

For agricultural producers the most important thing is to provide stable sales of their products. Due to the requirements of high quality, affordable price and well-packaged products, small and medium-sized enterprises are not able to compete with regular suppliers. Traditional lack of action coordination of enterprises in various spheres of agricultural complex and contradictions of their interests is also disturbing (Actual Problems of Development..., 2015). The small size of livestock farms in agricultural enterprises and peasant (farmer) farms cannot provide the continuity of the process that determines low efficiency and low competitiveness of agricultural products. In this aspect, the improvement of the forms of interaction between enterprises, finding the ways of consolidation of farms, their association on the basis of cooperation becomes important. At the present, the process of cooperation in the agricultural complex of the republic passes spontaneously, without proper organizational and economic arguments and the lack of a strong regulatory framework that defines the legal and economic basis for their creation, an effective mechanism of their functioning (The Cooperatives in EC Agriculture).

Development of cooperation in the agricultural sector today requires new approaches, providing the stabilization of the economy of agricultural complex, the study of theory, methodology and practice of development of agricultural cooperation, the development of substantiated mechanism to improve the efficiency of agricultural cooperative system, the mechanism of formation and functioning of the prospective models, and regulation of economic relations between the partners in the agricultural complex on a voluntary basis. These mechanisms shall take account of market conditions, the choice of one or another form of cooperation that has variant solutions, as well as the existing legal character, based on the local and state regulation (Manko et al., 1992).

In general, substantiated the need of acceptance for organizational and economic measures to improve the efficiency of agricultural cooperation, in particular, of the adoption of measures to improve the regulatory framework, financial and loan mechanism, activation measures of state support and regulation, and others activities to form a unified system of agricultural cooperation that will contribute to growth in the number and distribution of agricultural cooperatives of horizontal and vertical types (Manko et al., 1992).

The main directions of financial and credit support for agricultural cooperatives are:

$\square$ creation of a cooperative bank on the experience of countries with developed market economics (Japan, Germany, China, and others), where the long-term credits, loans, leasing, governmental subsidies allow quite effective realization of state agrarian programme on development of agricultural cooperation and support for small forms managing (Paptsov, 2011; Yegorov, 2012);

$\square$ giving subsidies for reimbursement of the cost of interest on loans received by agricultural cooperatives on the experience of countries with developed market economics and the (IS countries (Russia, etc.), (Paptsov, 2011; Yegorov, 2012);

$\square$ making arrangements to simplify the provision of concessional loans under the terms of JSC "Agrarian Credit Corporation", "KazAgroFinance", etc. and the availability of not only for the RCC, but also for RCCWU, PC, may stop the process of dissolution of the PC in the RCC, peasant farms, conversion RCCWU in the RCC, etc.; 
$\square$ financing of agricultural cooperatives in the framework of state programs on support of agricultural producers;

$\square$ creation of a guarantee fund for loans to banks and leasing companies, specialized credit bureau (bank of credit history data);

$\square$ formation of the trust fund's financial and credit support for the first forms of the agricultural cooperatives;

$\square$ assistance in the development of a network of microfinance institutions.

One of the conditions for the successful development of agricultural cooperatives in rural areas is the creation of a unified system of agricultural cooperatives, which is a complex of cooperatives of various types and levels, in the organizational-legal and functional relationships, associated on state, regional and district levels. The mechanism of increase of efficiency of development in agricultural cooperatives provides for the gradual formation of a multi-level system of agricultural cooperatives operating in interrelationship with the state (local) authorities by the formation of the Coordination Council and working groups of consultants on the issues of organization forms of agricultural cooperation on the district level, as well as their interaction with financial, social and other organizations (Exploring Agricultural Taxation in Europe, 2007).

Formation and development of agricultural cooperatives system will: protect and realize economic and social interests of small forms of managing by means of their self-organization and self-activity, ie, at the expense of their own funds; realize mobilization and included in the economic circulation unused resources, especially in the primary economic links; organize effective cooperative forms of infrastructure, serving agriculture, connecting the interests of all participants of the production, processing and marketing of agricultural products; link the differentiation of incomes of rural workers with the results of their activities, i.e. implement measures to facilitate the achievement of social justice, improving the social situation of the rural population and the weakening of the increased social tensions; to increase employment and incomes of the rural population (Cooperative Principles and Statutes,..., 1997).

As a result of the recommended mechanism of improving the efficiency of agricultural cooperatives, sufficient legal basis for the development of small forms managing and agricultural cooperatives will be formed, defining the legal conditions of their state support. For farmers, owners of personal subsidiary farms and rural entrepreneurs there will be significantly expanded access for the financial and credit resources, including at the expense the development of credit and insurance cooperatives. It will be an efficient system of servicing peasant farms, personal subsidiary farms, small enterprises and sales of their products on a cooperative basis. Rural population will significantly expand its access to market information, consulting services, and advanced training services. For the purpose of effective realization of the recommended mechanism, we have developed the stages of creation and development of agricultural cooperatives, at the level of each district, which are divided into activities for the first-initial and final stage (Akimbekova, 2012).

\section{References}

ACTUAL PROBLEMS of Development of Cooperation and Integration in the Agricultural Complex of the Republic of Kazakhstan. Materials of scientific-practical conference "Strategy of Development of Agricultural Complex and Rural Development : Perspective Ideas and Competitive Technology". In FGBNU VNIOPTUSH, 19-20 February, Moscow, Russia, 2015.
AGRICULTURE, FORESTRY AND FISHING OF KAZAKHSTAN. Statistical Yearbook, 20112016, Agency on Statistics of the Republic of Kazakhstan.

AKIMBEKOVA, G. Agroindustrial Integration : Theory, Practice, prospects. Almaty, Kazakhstan, 2012,330 p.

AKIMBEKOVA, G. et al. Evaluation of Agricultural Cooperative's Activities and the Mechanism of Improving their Effectiveness in the Republic of Kazakhstan (the methodological recommendations) LLP "Kazakh Research Institute of Economy Agribusiness and Rural Development", Almaty, Kazakhstan, 2011.

AKIMBEKOVA, G. Legislative Basic of Agricultural Cooperatives of Kazakhstan: Issues and Solutions. In Issues of Agricultural Market, Almaty, Kazakhstan, 2012, no. 1.

AKIMBEKOVA, G. The Objective Necessity of Creation and Development of Agricultural Service Cooperatives in the Republic of Kazakhstan. In Food and Processing the Industry of Kazakhstan, 2011, no. 2.

AKIMBEKOVA, G. - AYULOV, A. - YEGIZBAYEVA, G. Cooperation of Small Farms in Agricultural Complexof Kazakhstan. In Issues of Agricultural Market. Almaty, Kazakhstan, 2015, no. 2, p. 80.

COOPERATIVE PRINCIPLES AND STATUTES, Legal Description of Unique Enterprises. N.Y. 1997. p. 9.

DATA OF ANNUAL REPORTS APC "Breeding Plant "Almaty" Talgar district of Almaty region, 2015.

DATA OF ANNUAL REPORTS of RCC "Besketik" Maktaaral district of South Kazakhstan region, Kazakhstan, 2015.

DATA OF ANNUAL REPORTS of RCCWU “Dostyk" Maktaaral district of South Kazakhstan region, Kazakhstan, 2015.

DATA OF THE DEPARTMENT of Agriculture on Statistics of Almaty and South Kazakhstan regions, Kazakhstan, 2015

EXPLORING AGRICULTURAL TAXATION IN EUROPE. LEI. The Hague. 2007. 207 p.

MANKO, V. et al. 1992. The Formation of Cooperative Relations in the Activities of Agroindustrial Complexes, Associations and Agricultural Companies. Kiev : Harvest, Ukraine, 1992, p. 48.

PAPTSOV, A. 2011. Agricultural Cooperation in the Abroad. Conditions and Prospects of Development of Cooperation in the Agricultural Sectorof Economy - M. : LLC "Sunrise A", Russia, 2011, p. 135.

SUNDETOV, Zh. 2005. Corporate Strategy. Astana : EAGl, Kazakhstan, 2005, 105 p.

THE COOPERATIVES IN EC AGRICULTURE. Copenhagen. $15 \mathrm{p}$.

THE LAW OF THE REPUBLIC OF KAZAKHSTAN "On Rural Consumer Cooperatives of Water Users." Almaty : LAWYER, 2003. http://adilet.zan.kz/rus/docs/Z030000404_ 15.11.2014

THE LAW OF THE REPUBLIC OF KAZAKHSTAN "On the Rural Consumer Cooperation in the Republic of Kazakhstan. http://online.zakon.kz/document/?doc_id=1014010 15.11.2014

YEGOROV, V. 2012. World Experience of Development Cooperation in Agriculture. Agricul-tural Complex: Economics and Management. Russian Research Institute of Agricultural Economics. Russia, 2012, no. 1, p. 87-94.

\section{Contact address}

Galiya Akimbekova, LLP "Kazakh Research Institute of Economy Agribusiness and Rural Development", Head of the Department" Cooperation and Integration in Agriculture" Almaty, Republic of Kazakhstan, e-mail: akimbekova_g@mail.ru 